\title{
ADOPSI INOVASI MEDIA KOMUNIKASI PEMASARAN UMKM BATIK JUMPUTAN DI ERA DIGITALISASI
}

\author{
Riski Damastuti \\ Universitas AMIKOM Yogyakarta
}

\begin{abstract}
Marketing communication media develops as technology develops. Adaptation and adoption of digital marketing communication media is a challenge for UMKM Batik Jumputan Tahunan Yogyakarta. The purpose of this study is to find out how the process of adoption of digital marketing communication media in kelompok UMKM batik jumputan Tahunan, Yogyakarta. The method used in this research is descriptive qualitative. The data in this study were obtained through in-depth interviews with parties related to UMKM batik jumputan Tahunan, Yogyakarta, as well as direct or indirect observations of the digital marketing communication process carried out. The results of this study, it is known that the adoption of digital marketing communication media by kelompok UMKM batik jumputan Tahunan, Yogyakarta are still very low.
\end{abstract}

\section{Keywords}

UMKM, adoption of innovation, marketing communication

Correspondence Contact
riskidamastuti@amikom.ac.id

\section{PENDAHULUAN}

UMKM (Usaha Mikro, Kecil, dan Menengah) merupakan salah satu sektor penting yang selalu berusaha untuk dikembangkan oleh pemerintah. UMKM memegang peranan penting dalam perkembangan ekonomi suatu negara, karena dengan modal yang tidak begitu banyak, UMKM dapat menyerap banyak tenaga kerja daerah. Arief Budimanta, selaku wakil Komite Enonomi dan Industri Nasional menyatakan bahwa pada tahun 2017, dari total UMKM, terdapat 98,7\% usaha mikro di Indonesia, dan menyerap sebanyak 89,17\% tenaga kerja domestik. Produk UMKM yang kebanyakan masih lekat dengan lokalitas khas Indonesia diharapkan dapat berkembang dan berperan besar bagi perekonomian Indonesia, khususnya dalam kegiatan ekspor dan investasi.

Perkembangan UMKM di Daerah Istimewa Yogyakarta (DIY) berkembang dengan pesat. Dari data hasil Paparan Rakornas yang dibagikan kepada publik, diketahui bahwa jumlah UMKM DIY meningkat tiap tahunnya.

Tabel 1. Peningkatan Jumlah UMKM Yogyakarta

\begin{tabular}{|c|c|}
\hline Tahun & Jumlah UMKM \\
\hline 2015 & 220.703 \\
\hline 2016 & 230.047 \\
\hline 2017 & 238.619 \\
\hline
\end{tabular}

Sumber: Rakornas DIY 2018

Dari data tersebut, terlihat bahwa terjadi peningkatan pada jumlah UMKM di DIY. Bahkan pertumbuhan ini makin pesat di tahun 2018, dimana jumlah UMKM di 4 kabupaten dan 1 kota di DIY meningkat menjadi 258.000 , dengan $90 \%$ adalah pelaku usaha mikro dari berbagai sektor usaha. 
Dari data Rakornas DIY 2018, diketahui bahwa jumlah UMKM yang terdaftar di Kota Yogyakarta tidak sebanyak jumlah UMKM di 4 kabupaten lain. Berbagai upaya pengembangan UMKM dilakukan oleh pemerintah Kota Yogyakarta. Beberapa upaya pengembangan tersebut dilakukan dengan program "Gandeng Gendong" dan implementasi JSS (Jogja Smart Service). Program Gandeng Gendong menekankan pada partisipasi lima sektor dalam mengentaskan kemiskinan, yaitu komunitas, kampung, kampus, pihak swasta, serta Pemerintah Kota Yogyakarta. Dalam program "Gandeng Gendong", kelompok masyarakat dan UMKM diberikan kesempatan untuk menjadi penyedia kuliner maupun kerajinan pada setiap acara yang diadakan oleh Pemerintah Kota Yogyakarta. Sedangkan aplikasi Jogja Smart Service (JSS) fokus kepada penggunaan aplikasi digital yang berisi berbagai informasi tentang kota Yogyakarta, termasuk informasi mengenai UMKM.

Sebagai sentra usaha produk lokal, Kampung Batik Jumputan di Tahunan Umbulharjo Yogyakarta merupakan salah satu pusat UMKM batik yang memiliki ciri lokalitas khas Indonesia. Konsep Kampung Batik Jumputan muncul tujuh tahun lalu, dimana saat ini konsep Kampung Batik Jumputan semakin menguat karena hampir setiap rumah di Tahunan menjalankan usaha batik jumputan. Dari hasil wawancara pra riset, diketahui bahwa pemerintah memberikan perhatian yang tinggi pada Kampung Batik Jumputan hingga merencanakan Kampung Batik Jumputan menjadi Sentra Fashion Kota Yogyakarta. Dalam memperkenalkan Kampung Batik Jumputan, pemerintah melakukan berbagai upaya, tidak hanya dengan mengadakan pelatihan - pelatihan untuk meningkatkan kompetensi perajin, namun juga mengadakan berbagai acara, seperti Jumputan on The Street (2018), Smell River Festival (2019), dan Bazaar Jogja Heboh (2020).

Melihat perkembangan teknologi, khususnya media komunikasi pemasaran yang berpotensi untuk mendukung perkembangan UMKM, pemerintah Kota Yogyakarta melakukan berbagai program pengembangan bagi pelaku UMKM. Salah satu pengembangan komunikasi pemasaran UMKM adalah dengan mulai mensosialisasikan penggunaan media komunikasi pemasaran digital. Pengembangan UMKM melalui media komunikasi pemasaran digital mulai gencar dilakukan pemerintah pada tahun 2019 dengan mengadakan program UMKM Go Online!. Salah satu program UMKM Go Online! adalah pengembangan aplikasi Jogja Smart Service serta fitur dodolan dan nglarisi, yang diresmikan pada 27 Juni 2010. Dodolan dan Nglarisi merupakan sarana informasi dan jual beli bagi produk UMKM Kota Yogyakarta.

Selain memberikan fasilitas aplikasi jual beli, pemerintah juga berusaha mengembangkan kemandirian UMKM untuk berjualan di berbagai platform jual beli online. Pentingnya kemandirian pelaku UMKM dalam praktik jual beli online sangat diperlukan mengingat ketatnya persaingan usaha. Hal ini tentunya menjadi sebuah tantangan dan solusi baru bagi para pengelola kerajian batik jumputan untuk mulai bertransformasi menggunakan teknologi dalam mengembangkan komunikasi pemasaran produknya.

Terdapat berbagai penelitian yang dilakukan berkaitan dengan UMKM dan komunikasi pemasaran di era digital. Penelitian yang dilakukan Lisa Harris dan Allan Rae (2009) "Social Networks: The Future of Marketing For Small Business" memberikan gambaran mengenai kekuatan dari komunitas online terhadap brand reputation dan membangun hubungan secara online dengan pelanggan. Dalam penelitian tersebut, dijelaskan bahwa penting bagi usaha kecil untuk membangun brang image dan brand reputation, yang dapat dilakukan melalui blogging dan micro blogging dengan memanfaatkan media sosial. Selain itu, usaha kecil juga perlu untuk membangun social networking yang akan berimplikasi kepada promosi dan pertumbuhan usaha. Dalam penelitian ini juga disebutkan bahwa penggunaan teknologi komunikasi pemasaran akan menjadi solusi bagi usaha kecil yang tidak memiliki banyak biaya untuk pemasaran. Penelitian lain mengenai komunikasi pemasaran UMKM dilakukan oleh 
Muhammad Badri (2011) "Komunikasi Pemasaran UMKM di Era Media Sosial”. Penelitian ini dilakukan dengan mengkaji UMKM yang ada di Indonesia secara umum. Pembahasan komunikasi pemasaran dalam penelitian ini fokus pada komunikasi pemasaran melalui media sosial yang meliputi pemilihan media sosial, pemilihan konten, pengemasan pesan, dan membangun jaringan pemasaran global dan lokal. Dari deskripsi yang telah dipaparkan, dapat disimpulan bahwa kedua penelitian tersebut membahas mengenai aplikasi komunikasi pemasaran melalui media sosial pada UMKM.

Berdasarkan permasalah dan tinjauan penelitian terdahulu yang telah diuraikan, maka penelitian ini bertujuan untuk mengetahui bagaimana kelompok UMKM batik jumputan Tahunan Yogyakarta melakukan adopsi inovasi media komunikasi pemasaran digital, serta apa saja hambatan yang dialami dalam menggunakan media komunikasi pemasaran digital. Hasil penelitian ini diharapkan dapat menjadi pertimbangan bagi pemerintah untuk merancang program terkait pengembangan keahlian UMKM di Yogyakarta dalam menggunakan media komunikasi pemasaran digital.

\section{KAJIAN TEORITIK}

\section{Media Komunikasi Pemasaran Di Era Digital}

Dalam kajian pemasaran, terdapat istilah bauran pemasaran (marketing mix). Bauran pemasaran diperlukan untuk mencapai tujuan pemasaran, serta mengkomunikasikan pesan kepada khalayak (Kotler, 2003:15). Konsep awal bauran peasaran terdiri dari 4P, yaitu Product (Produk), Price (Harga), Place (Tempat), Promotion (Promosi). Dalam pemasaran jasa, konsep ini berkembang menjadi 7P dengan menambahkan unsur non - traditional marketing mix, yaitu People (Karyawan), Process (Proses), dan Physical Evidence (Bukti Fisik).

Dalam konsep bauran pemasaran, komunikasi pemasaran erat kaitannya dengan Promotion (Promosi). Promosi merupakan kegiatan komunikasi persuasif untuk meninformasikan produk atau jasa kepada khalayak dengan menggunakan berbagai media, diantaranya promosi penjualan, iklan, publisitas, serta pemasaran langsung (Kotler, 2003:16). Pemilihan media yang tepat memegang peranan penting dalam pengelolaan merek produk atau jasa. Penggunaan media yang tepat dapat membantu sebuah merek untuk dapat menyampaikan pesan secara efektif kepada khalayaknya. Dalam upaya mempromosikan sebuah produk atau jasa, sebuah merek perlu untuk membangun saluran komunikasi, merancang pesan persuasi, serta mengkomunikasikan gagasan dari produk atau jasa yang ingin dipasarkan (Michael Ray dalam Morissan, 2007:13).

Media komunikasi pemasaran berkembang semakin kreatif. Perkembangan teknologi menjadi salah satu faktor penyebab berkembangnya media komunikasi pemasaran. Media komunikasi pemasaran konvensional, kini mulai bertransformasi menjadi media komunikasi pemasaran digital. Media komunikasi pemasaran digital erat kaitannya dengan media baru. Dengan karakteristik media baru yang interaktif, massif, serta dapat menyesuaikan pengguna, maka media baru menjadi salah satu media yang kerap dijadikan media komunikasi pemasaran. Tedapat 5 kategori utama media baru yang dapat digunakan sebagai media komunikasi pemasaran, yaitu: 
Tabel 1.

Kategori Media Baru

\begin{tabular}{|l|l|}
\hline \multicolumn{1}{|c|}{ Kategori } & \multicolumn{1}{c|}{ Definisi } \\
\hline $\begin{array}{l}\text { Media komunikasi antar } \\
\text { pribadi }\end{array}$ & $\begin{array}{l}\text { Media yang digunakan untuk berkomunikasi dengan } \\
\text { orang lain, dengan konten yang bersifat pribadi }\end{array}$ \\
\hline $\begin{array}{l}\text { Media permainan interaktif } \\
\text { (interactive play media) }\end{array}$ & $\begin{array}{l}\text { Media berbasis pada permainan virtual yang interkatif } \\
\text { dan didominasi kepuasan dari penggunaannya }\end{array}$ \\
\hline $\begin{array}{l}\text { Media pencarian informasi } \\
\text { (information media search) }\end{array}$ & $\begin{array}{l}\text { Media yang digunakan sebagai sumber data yang ukuran, } \\
\text { aktualitas, dan aksesibilitasnya belum pernah ada } \\
\text { sebelumnya }\end{array}$ \\
\hline $\begin{array}{l}\text { Media partisipasi kolektif } \\
\text { (collective participatory } \\
\text { media })\end{array}$ & $\begin{array}{l}\text { Media yang digunakan untuk berbagi dan bertukar } \\
\text { informasi, gagasan, dan pengalaman, serta } \\
\text { mengembangkan hubungan pribadi }\end{array}$ \\
\hline $\begin{array}{l}\text { Substitusi media penyiaran } \\
\text { (substitution of broadcasting } \\
\text { media) }\end{array}$ & $\begin{array}{l}\text { Media yang digunakan untuk menerima atau mengunduh } \\
\text { konten yang di masa lalu biasanya disiarkan dengan } \\
\text { metode lain }\end{array}$ \\
\hline
\end{tabular}

McQuail (2014) mengelompokkan media baru menjadi 5 kategori. Kategori pertama adalah media komunikasi interpersonal yang terdiri dari email, sms, telfon, aplikasi berkirim pesan seperti whatsapp, line. Kategori kedua adalah media permainan interaktif, seperti video game, aplikasi permainan yang dapat diunduh. Kategori ketiga adalah media pencarian informasi yang berupa portal, seperti Google, Yahoo. Kategori keempat adalah media partisipasi kolektif yang dapat digunakan untuk pertukaran informasi, pendapat dan pengalaman, misalnya Facebook, Instagram, Twitter. Kategori teakhir adalah media yang merupakan subtitusi media penyiaran, seperti Youtube. Adaptasi dan melakukan berbagai inovasi menjadi salah satu tantangan komunikasi pemasaran di era digital yang disruptif.

\section{Adopsi dalam Difusi Inovasi}

Pemahaman difusi inovasi dimulai dari pemahaman kata difusi dan inovasi. Divusi merupakan sebuah proses penyampaian inovasi melalui saluran tertentu, selama waktu tertentu kepada sebuah sistem sosial . Inovasi merupakan sebuah gagasan, praktik, atau benda yang dianggap baru oleh individu atau sekelompok masyarakat. Sehingga dapat disimpulkan bahwa difusi inovasi merupakan sebuah proses peyampaian sebuah gagasan yang dianggap baru kepada sebuah kelompok masyarakat dalam jangka waktu tertentu (Rogers, 1983: 10). Dari definisi tersebut, dapat diketahui bahwa difusi inovasi terdiri dari empat elemen pokok, yaitu:

Inovasi, merupakan sebuah gagasan, tindakan, ataupun barang yang dianggap baru oleh seseorang atau sekelompok masyarakat.

Saluran komunikasi, mencakup alat - alat yang digunakan untuk mengkomunikasikan inovasi dari sumber inovasi kepada penerima. Dalam memilih saluran komunikasi, perlu untuk memperhatikan tujuan diadakannya komunikasi dan karakteristik penerima. 
Jangka waktu, merupakan dimensi dari sebuah proses mulai dari seseorang mengetahui sebuah inovasi sampai mengambil keputusan terhadap inovasi tersebut.

Sistem sosial, adalah sekumpulan masyarakat yang berbeda secara fungsional, namun terikat dalam kerjasama untuk memecahkan masalah dalam rangka mencapai tujuan bersama.

Awalnya Rogers (1983:163) menyatakan bahwa terdapat 5 tahap dalam proses penerimaan terhadap inovasi, yaitu: Tahap Awareness (Kesadaran), Tahap Interest (Keinginan), Tahap Trial (Mencoba), serta Tahap Adoption (Adopsi). Namun proses difusi inovasi mengalami perkembangan dalam tahapannya. Proses penerimaan inovasi tidak hanya dipengaruhi oleh faktor internal penerima, namun juga pengaruh lingkungan penerima adopsi. Maka, Rogers (1983) melakukan revisi pada teori Difusi Inovasi, bahwa terdapat 5 tahap dalam proses penerimaan inovasi, yaitu Tahap Knowledge (Pengetahuan), Tahap Persuasion (Persuasi), Tahap Decision (Keputusan), Tahap Implementation (Pelaksanaan), serta Tahap Confirmation (Konfirmasi).

Gambar 1. Proses Pengambilan Keputusan Inovasi

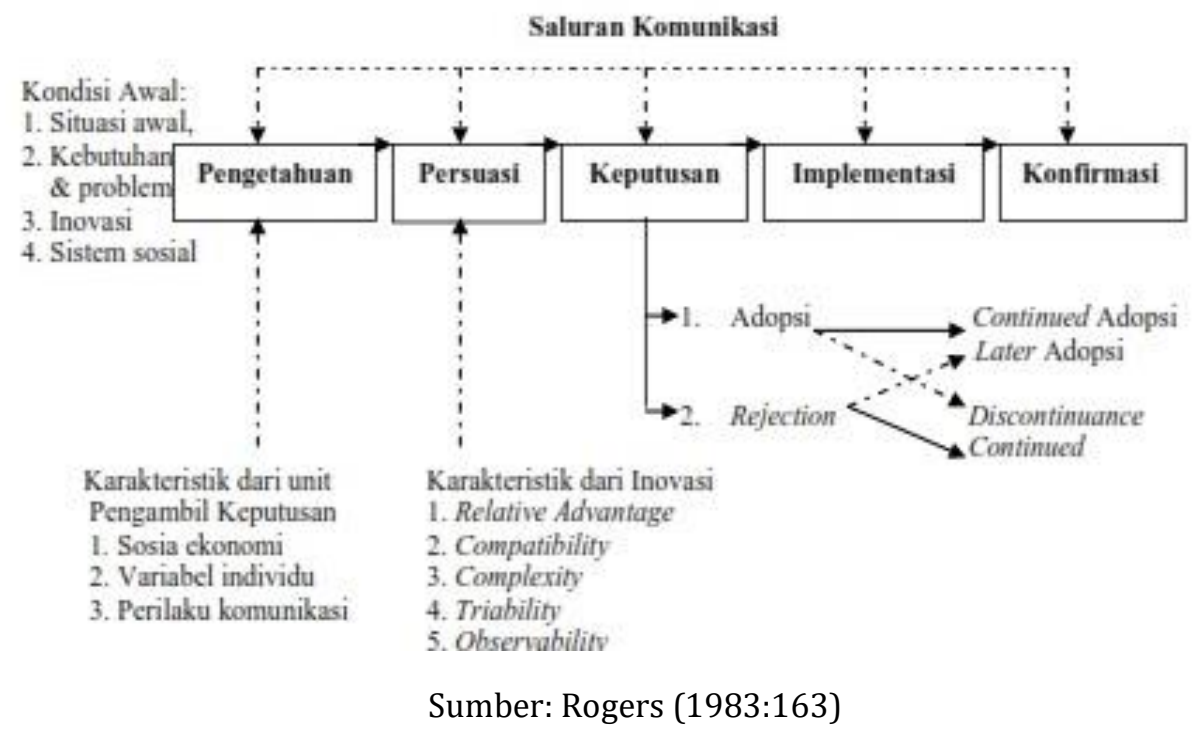

Dalam proses penerimaan oleh sekelompok masyarakat, sebuah inovasi memiliki beberapa karakteristik sifat - sifat tertentu yang akan mempengaruhi kecepatan mengadopsi inovasi (Rogers, 1983:210), yaitu:

1. Keuntungan relatif (relative advantages), sejauh mana sebuah inovasi dianggap lebih baik dari ide sebelumnya.

2. Kesesuaian (compability), sejauhmana sebuah inovasi sesuai dengan nilai - nilai yang ada, pengalaman masa lalu, serta kebutuhan penerima. Sebuah inovasi yang tidak sesuai dengan nilai - nilai sosial penerima akan lebih sulit untuk diadopsi.

3. Kerumitan (complexity), sejauh mana sebuah inovasi dianggap sulit atau mudah dimengerti oleh penerima. Kerumitan sebuah inovasi dapat menjadi hambatan bagi proses kecepatan adopsi inovasi.

4. Kemungkinan untuk dicoba (trialibility), sejauh mana kemudahan sebuah inovasi dapat dicoba dalam skala kecil. Sebuah inovasi yang dapat dicoba dalam skala kecil 
biasanya akan lebih diadopsi daripada inovasi yang tidak dapat dicoba terlebih dahulu.

5. Mudah diamati (observability), sejauh mana hasil dari sebuah inovasi dapat dengan mudah diamati sebagai keuntungan ekonomis.

Selain dipengaruhi oleh sifat inovasi, kecepatan adopsi inovasi juga dipengaruhi oleh tipe keputusan yang dibuat, antara lain:

1. Keputusan opsional, merupakan keputusan yang dibuat oleh seseorang dengan mengabaikan keputusan orang lain dalam sebuah sistem sosial.

2. Keputusan kolektif, merupakan keputusan yang dilakukan oleh beberapa orang dalam suatu sistem sosial yang telah dimufakati atau disetujui bersama.

3. Keputusan otoritas, merupakan kepurusan yang dipaksakan oleh seseorang yang memiliki kekuaaan lebih besar.

Adopsi merupakan salah satu tahap dalam proses difusi inovasi. Seseorang dikatakan mengadopsi inovasi jika proses perubahan perilaku, baik pengetahuan, sikap, maupun ketrampilan setelah menerima inovasi yang disampaikan. Terdapat 5 jenis adopters:

\section{Gambar 2. Kategori Adopter}

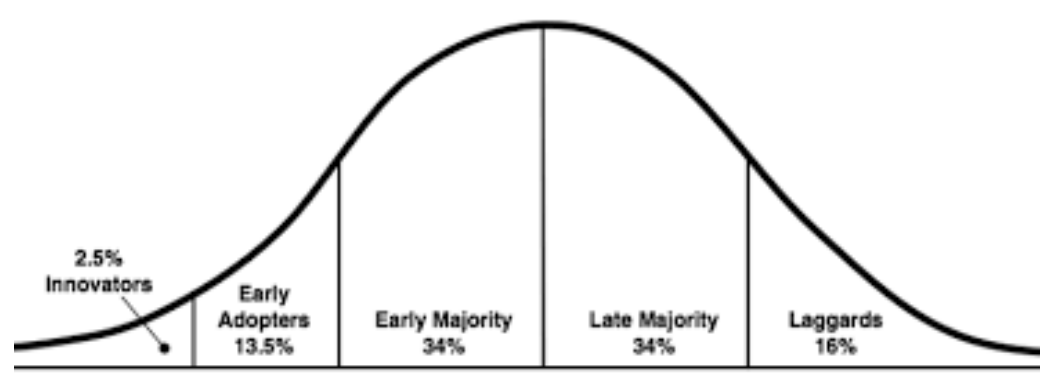

Sumber: Rogers (1983:243)

Kurva tersebut memberikan gambaran tentang jumlah adopter dari waktu dimulai nya penyebaran inovasi, hingga jumlah pengadopsi menurun. Setiap adopter memiliki karakteristik yang berbeda - beda. Seorang innovator merupakan pelopor bagi adopter lainnya. Innovator memiliki karakteristik berani mengambil resiko, dan biasanya berjumlah sangat sedikit. Early adopters merupakan orang - orang yang berpengaruh dalam sebuah sistem sosial. Early adopters biasanya akan berusaha mencari inovasi yang dapat memberikan keuntungan dalam kehidupan sosial atau ekonominya. Early majority merupakan orang orang yang sangat berhati - hati dalam mengadopsi sebuah inovasi. Early adopters dan early majority merupakan opinion leader bagi orang - orang disekitarnya. Late majority dan Laggard merupakan golongan konservatif yang pragmatis pada inovasi. Late majority akan mencoba inovasi setelah melihat contoh. Anti klimaks dari kurva kategori adopter adalah Leggard. Leggard memandang inovasi sebagai sesuatu yang memiliki resiko tinggi. 
Penelitian ini merupakan penelitian deskriptif kualitatif yang menggunakan metode fenomenologi. Penelitian kualitatif bertujuan untuk memahami (understanding) makna yang disimbolkan dalam perilaku masyarakat menurut perspektif masyarakat itu sendiri (Suprayogo, 2001:1). Penelitian ini juga termasuk dalam penelitian fenomenologi yang menghasilkan sebuah deskripsi reflektif yang mendalam dari sebuah pengalaman (Denzin\&Lincoln, 2009:283). Dalam konteks penelitian ini, fenomena yang dikaji adalah adaptasi dalam proses difusi inovasi media komunikasi pemasaran pada UMKM Batik Jumputan Tahunan Yogyakarta.

Penelitian ini dilakukan di Kelurahan Tahunan, Umbulharjo Yogyakarta yang merupakan daerah penghasil kerajinan batik jumputan. Di Kelurahan Tahunan terdapat sekitar 8 kelompok UMM batik Jumputan. Tiap kelompok dipimpin oleh seorang ketua kelompok dan memiliki 10 hingga 20 orang pengrajin batik jumputan. Kelurahan Tahunan merupakan salah satu sentra fashion yang mulai dikembangkan oleh pemerintah. Upaya pengembangan ini dilakukan dengan berbagai cara, mulai dari mengadakan berbagai acara wisata, hingga sosialisasi penggunaan teknologi pada pelaku UMKM.

Dalam penelitian ini, teknik pengumpulan data dilakukan dengan mencari data primer dan data sekunder. Data primer diperoleh dengan melakukan wawancara mendalam dengan ketua tiap UMKM Batik Jumputan di Kelurahan Tahunan. Dalam penelitian ini, digunakan data sekunder untuk melengkapi data - data primer. Pengumpulan data sekunder dilakukan dengan melakukan wwawancara tak terstruktur dengan warga dan tokoh masyarakat Tahunan, observasi aktivitas komunikasi pemasaran yang dilakukan oleh UMKM Batik Jumputan Tahunan, serta mengkaji literatur yang berkaitan dengan konsep penelitian.

\section{HASIL DAN PEMBAHASAN}

Proses adopsi inovasi komunikasi pemasaran digital pada UMKM Batik Jumputan Tahunan sangat didukung oleh pemerintah. Dalam paparan Rakornas Yogyakarta 2018, dukungan pemerintah diwujudkan dalam Program Pemberdayaan dan Pendampingan KUMKM untuk meningkatkan daya saing UMKM Kota Yogyakarta. Proses adopsi inovasi dilakukan dengan sosialisasi UMKM Go Online! dengan mengundang pelaku UMKM Kota Yogyakarta, serta diadakannya berbagai pelatihan terkait konsep komunikasi pemasaran dan pengelolaan sosial media untuk komunikasi pemasaran.

Gambar 3. Tampilan Website Pemerintah Kota Yogyakarta

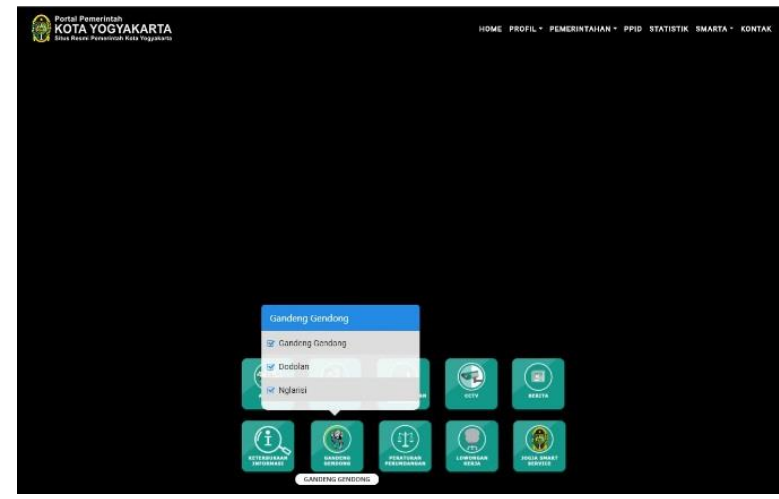

Sumber: https://www.jogjakota.go.id/

Gambar 4. Tampilan "Dodolan" pada Website Pemerintah Kota Yogyakarta 


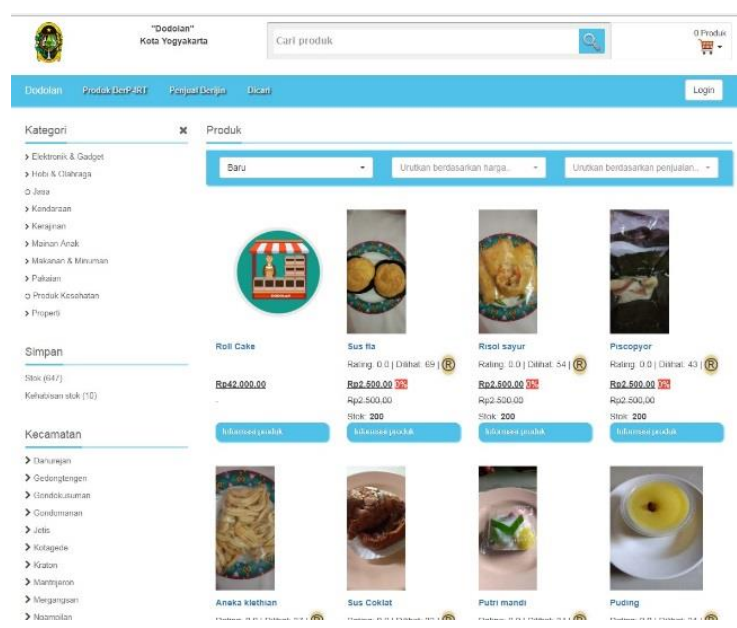

Sumber: https://dodolan.jogjakota.go.id/

Upaya pemerintah dalam mengembangkan komunikasi pemasaran melalui aplikasi pemerintah Kota Yogyakarta belum menjadi pilihan bagi perajin batik jumputan. Hal ini terlihat dari tidak ada perajin batik yang menggunggah produknya pada website tersebut.

Bagi para pengrajin batik jumputan, salah satu cara komunikasi pemasaran yang banyak diandalkan word of mouth marketing. Word of mouth marketing menjadi tolak ukur bahwa karya batik yang dihasilkan membuat konsumen puas, sehingga konsumen akan bercerita kepada orang lain, seperti yang dikatakan Pak Aziz (Ketua Kelompok Batik Songo):

"Saya jarang pakai media sosial. Paling ya cuma update motif di status whatsapp, itu aja jarang. Rata - rata yang beli kesini karena informasi dari teman atau konsumen lama. Kalau pembeli puas kan dia akan cerita ke orang lain" (Aziz, wawancara, 5 Januari 2020)

Dari pernyataan tersebut, dapat dilihat bahwa dalam melakukan komunikasi pemasaran, upaya Pengrajin Batik Jumputan untuk membangun kesadaran khalayak terhadap merek (brand awareness) masih rendah. Banyak dari pengrajin yang hanya menginformasikan mengenai jenis produk dan harga produk tanpa melakukan edukasi merek kepada khalayak. Banyak pengrajin yang memiliki profesi diluar batik jumputan, sehingga merasa tidak memiliki banyak waktu untuk melakukan kegiatan yang berkaitan dengan brand awareness. Namun, terdapat salah satu pengrajin yang memiliki kesadaran tinggi akan brand awareness , yaiatu Ibu Tuliswati Sandhi (Ketua Kelompok Jumputan Dea Modis)

"Saya selalu pakai batik jumputan kalau pergi kemana - mana, karena saya bangga dengan karya saya. Kalau pameran atau pergi kemana - mana saya selalu pakai batik jumputan. Dan banyak orang jadi tertarik dan bertanya - tanya tentang jumputan." (Tuliswati, wawancara, 3 Januari 2020)

Proses difusi inovasi media komunikasi pemasaran pengrajin Batik Jumputan dilakukan oleh pemerintah dengan diadakannya berbagai pelatihan berkaitan dengan penggunaan teknologi dan edukasi konsep konsep yang berkaitan dengan komunikasi pemasaran. Pemerintah memberikaan pelatihan fotografi produk, membuat narasi caption, serta menentukan waktu posting yang tepat. Banyak pengrajin batik jumputan yang mengikuti pelatihan tersebut, namun hanya sedikit peningkatan pengetahuan dan minat untuk menggunakan media digital sebagai media komunikasi pemasaran. Hal ini dinyatakan oleh Mini (Ketua Batik Jumputan Batikan Mini Budiyono) 
"Saya tau, tapi gak pakai instagram mbak. Ya cuma tau aja, tapi males pakainya. Kalau pake instagram kan harus foto, harus diedit, masih harus bikin tulisannya, repot mba. Lagian udah faktor U (Usia) mbak. Saya kan gak cuma njumput mbak, saya juga njahit. Kalo saya pegang HP terus, kapan saya kerjanya?"(Mini, wawancara, 4 Januari 2020)

Beberapa pengrajin jumputan sepakat bahwa mereka merasa bahwa usia dan faktor sosio ekonomi menjadi hambatan dalam memahami teknologi. Penggunaan teknologi dalam komunikasi pemasaran dianggap memiliki tingkat kompleksitas (complexity) tinggi, sehingga tingkat adopsinya sangat rendah. Namun terdapat beberapa pengrajin yang mulai mengadopsi penggunaan teknologi dalam komunikasi pemsarannya. Dilihat dari usia dan sosio ekonomi, Dea Modis dan Lemospires memiliki karakteristik yang berbeda dengan kelompok batik lain. Dea Modis dan Lemospires mulai mengadopsi teknologi dalam komunikasi pemasarannya.

"Saya selalu update status whataspp biar orang - orang tau koleksi batik saya, yang lihat lumayan lo mbak, sekitar 200 orang, dan banyak yang dari luar kota. Terus biasanya ada yang tertarik dan beli batik. Jadi memang teknologi ini berguna sekali buat saya. Saya juga update status facebook lo. Saya gak cuma upload foto jualan, tapi juga kegiatan - kegiatan saya." (Tuliswati, wawancara, 3 Januari 2020)

Dari pernyataan tersebut, terlihat bahwa bagi beberapa kelompok pengrajin, penggunaan teknologi dalam media komunikasi pemasaran memberikan keuntungan (relative advantage), sehingga inovasi teknologi dapat lebih mudah diterima pada kelompok tersebut. Penggunaan teknologi dianggap dapat membantu proses penyampaian pesan kepada khalayak dengan tidak terbatas ruang dan waktu.

Dalam implementasi komunikasi pemasaran, karya yang dihasilkan oleh kelompok jumputan dipasarkan oleh ketua kelompok melalui media kovensional, event, maupun akun digital yang dimiliki oleh ketua kelompok. Salah satu akun digital yang paling sering digunakan untuk melakukan komunikasi pemasaran adalah whatsapp, karena whatsapp dianggap paling mudah digunakan. Platform media sosial seperti instagram, facebook, serta toko online masih belum sering digunakan.

"Saya gak bikin akun instagram, apalagi toko online mbak, gak ada yang ngurusin mbak,dan kalau di toko online itu kan harus ready terus barangnya, kalau misalkan habis kita harus edit lagi tokonya, jadi saya belum mampu bikin akun toko online" (Mini, wawancara, 4 Januari 2020)

"Kalau saya belum bikin akun toko online, gak ada yang ngurusin tokonya, lagian barang saya ini kan handmade, untuk pembuatannya tidak bisa dipatok waktu, padahal kalau ditoko online ada batas waktu pengiriman. Saya lebih seneng kalau orang yang mau beli batik tulis langsung datang ke toko, lihat dan pegang bahan. Kalau lihat cuma lihat di foto takut beda ekspektasinya, warna di HP kan bisa beda" (Aziz, wawancara, 5 Januari 2020)

Dari hasil wawancara tersebut, terlihat bahwa platform media sosial dan toko online belum maksimal digunakan karena terkendala kemampuan dan waktu pengelolaan. Salah satu solusi untuk memaksimalkan kegiatan komunikasi pemasaran adalah dengan menggunakan jasa content creator.

"Kalau ada yang ngurus media sosial sih saya mau, tapi bayar berapa mbak?Nanti udah bayar mahal - mahal, ternyata sama aja gak untung" (Mini, wawancara, 4 Januari 2020) 
Pernyataan tersebut senada dengan narasumber lain, bahwa penggunaan jasa content creator masih dianggap mahal bagi kelompok UMKM batik jumputan. Hasil dari jasa content creator tidak dapat dilihat dalam jangka waktu dekat, karena konteksnya adalah pembangunan brand awareness dibenak khalayak. Hal ini pernah dinyatakan oleh Slade dan Akkeren (2002) dalam risetnya di Australia bahwa UMKM akan lebih mudah mengadopsi sebuah inovasi teknologi yang dapat memberikan manfaat ekonomis atau mendukung Return On Investment (relative advantage dan observability).

\section{KESIMPULAN}

Dari hasil penelitian yang diperoleh, dapat ditarik kesimpulan bahwa adopsi teknologi dalam komunikasi pemasaran kelompok UMKM batik jumputan masih sangat rendah. Mayoritas pengrajin batik jumputan merupakan late majority, bahkan leggards dalam melakukan adopsi inovasi teknologi komunikasi pemasaran. Inovasi akan diadopsi ketika ada contoh, tidak rumit, atau dapat memberikan keuntungan. Dalam praktiknya, belum tercipta sistem yang menempatkan pemasaran sebagai salah satu bagian dalam bisnis batik jumputan. Hal ini menyebabkan komunikasi pemasaran tidak dapat berjalan dengan maksimal.

Melihat berbagai kendala yang berkaitan dengan motif sosio ekonomi dan kendala pribadi, penting bagi pemerintah untuk tidak hanya memberikan pelatihan, namun juga pembinaan jangka panjang bagi kelompok UMKM batik jumputan. Selain pelatihan dan pembinaan terkait penggunaan teknologi dalam komunikasi pemasaran, diperlukan juga upaya peningkatan kesadaran mengenai potensi komunikasi pemasaran digital dan pentingnya proses manajemen dalam sebuah bisnis.

\section{DAFTAR PUSTAKA}

Avianni, Nur. 2019. UMKM Harus Naik Kelas, Ini Resep dari KEIN. https://mediaindonesia.com/read/detail/238129-umkm-harus-naik-kelas-iniresep-dari-kein. Diakses pada 10 Desember 2019.

Badri, M. 2011. Komunikasi Pemasaran UMKM di Era Media Sosial. Dalam Irwansyah \& Budianto, H. (eds). Corporate and Marketing Communication, PP. 127 - 147, Jakarta: Puskombis Universitas Mercu Buana - Buku Litera.

Denzin , Norman K. Dan Yvonna S. Lincoln. 2009. Handbook of Qualitative Research. Terjemahan Dariyanto dkk. Yogyakarta: Pustaka Pelajar.

Harris, Lisa \& Rae, Alan. 2009. Social Network: The Future of Marketing For Small Business. Journal of Business Strategy. Vol 5.

Kotler Philip, Amstrong Gary. 2013. Prinsip - prinsip Pemasaran, Edisi Ke 12. Jakarta: Penerbit Erlangga.

McQuail, Dennis. 2014. Teori Komunikasi Massa. Jakarta: Salemba Humanika.

Morissan. 2007. Periklanan: Komunikasi Pemasaran Terpadu. Tangerang: PT Ramdina Prakarsa.

Rogers, M. Everett. 1983. Diffusion of Innovations. London: The Free Press.

Slade, P., dan Akkeren, J.V. 2002 Business Online? An Empirical Study of Factors Leading to the Adoption of Internet Technologies byAustralian SMEs. AJIS, 10(1). PP 50 - 64.

Suprayogo, Imam dan Tobroni. 2001. Metode Penelitian Kualitatif. Bandung: PT. Remaja Rosda Karya. 
Junaidi. Pemanfaatan Instagram Sebagai Media Dakwah Di Kalangan Mahasiswa Kabupaten Aceh Barat

Wicaksono, Pribadi. 2020. UMKM Yogya Belum Banyak Sentuh E-Commerce. https://bisnis.tempo.co/read/1191330/umkm-yogya-belum-banyak-sentuh-ecommerce. Diakses pada 2 April 2020

http://www.depkop.go.id/uploads/tx rtgfiles/22. Paparan Rakornas Yogyakarta 2018 _DIY.pdf

https://dodolan.jogjakota.go.id/

https://www.jogjakota.go.id/ 